\title{
Fisiologia: crises?
}

\section{ERASMO G. MENDES}

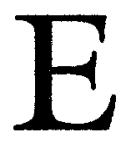

m um editorial de The Physiologist, Frank (1986) externou sua preocupação quanto ao futuro da fisiologia, tal como tradicionalmente é considerada. Recordou o matemático Hilbert, para quem "enquanto uma ciência oferecer abundância de problemas, estará viva, falta dos mesmos configura extinção ou cessaçáo de sua independência". Reconhecendo que ainda há profundas questôes a responder na fisiologia antes que seja atingido um entendimento abrangente de como os seres vivos funcionam, perguntou se, não obstante, ela teria ainda pela frente um futuro brilhante. A dúvida resultou das restriçóes que se vêm fazendo ultimamente à fisiologia em torno de tal futuro e da impressão geral de estar ela modernamente desmembrando-se em ciências afins, como a biofísica, a bioquímica, a farmacologia e, mesmo, a imunologia, em detrimento da pesquisa de caráter sistêmico, implicando uma visảo holística, em que vinha antes sendo praticada. Sim, de alguns ângulos, a fisiologia, como é classicamente entendida, vem sendo comparada, em equivalentes funcionais, à gross anatomy, no sentido de que, em seu aspecto sistêmico, haveria cada vez menos a pesquisar, cabendo os detalhamentos dos processos cada vez mais às ciências afins mencionadas, atuando independentemente.

De fato, a elucidação dos mecanismos íntimos do funcionamento do organismo vivo caminha crescente e inexoravelmente para a abordagem molecular ou biofísica e Frank vê nisso um perigo à sobrevivência dos departamentos de fisiologia nas universidades, em termos de descaracterização e conseqüente descredenciamento na disputa por financiamento de pesquisa junto às agências de fomento desta. Esse temor de Frank de um esvaziamento dos departamentos de fisiologia, face à dificuldade de fazer cutting edge research, tem fundamento, pois, para enfrentar a situação, tais departamentos já começam a se denominar, por exemplo, departamento de fisiologia e biofísica, como acontece na Universidade de São Paulo. Na Universidade Federal do Rio de Janeiro a fisiologia é ensinada (e pesquisada) num Departamento de Biofísica, sucessor do Laboratório de Biofísica criado por Carlos Chagas Filho, ao tempo em que essa universidade era a Universidade do Brasil.

Assim, a fisiologia, pelo menos a de cunho geral e sistêmico, estaria em crise e essa crise teria surgido, paradoxalmente, da evolução de sua pesquisa no sentido do aprofundamento e do esmiuçamento dos 
problemas de que sempre se ocupou. Confesso, porém, a não ser pelo perigo de perda de verbas para a pesquisa em favor das ciências em que se desmembrou (essas, apenas, estariam fazendo cutting edge research), não ver procedência nessa crise, pensando em termos de filosofia e história da ciência. Parece claro que esse desdobramento em ciências afins foi uma decorrência do avanço inevitável do emprego de procedimentos físicos e químicos na investigação fisiológica, desde que, numa memorável reunião feita em Berlim em 1847, Helmholtz, Ludwig, Du Bois Reymond e Brücke, top physiologists da época, recomendaram que, daí em diante, a pesquisa fisiológica se baseasse na física e na química, entáo em franco desenvolvimento. Náo vejo como esse procedimento possa ter levado, século e meio após, à invalidação da fisiologia clássica como disciplina científica autônoma, persisto antes na crença de que as ciências em que se desdobrou continuam ciencias fisiologicas, estando ainda longe o dia em que a fisiologia dos sistemas vivos como um todo ficará elucidada. A propósito, physiologia é palavra grega latinizada e significou originalmente conbecimento natural, como tal sendo também entendida por Jean Fernel (1497-1558), o Galeno Moderno, recordado agora apenas por suas obras que servem à compreensão da ciência da época e por ter sido médico da Dianne de Poitiers, amante de Henry II da França e do próprio rei. Com o tempo, gradualmente o sentido do termo foi se restringindo para designar o estudo das funçóes dos seres vivos, sendo atualmente até deturpado para tipificar as atividades de políticos adesistas contumazes. $\mathrm{O}$ conhecimento de como os animais funcionam foi inicialmente inferido das características anatômicas e de uma ocasional experimentação;somente a partir do descobrimento da circulaçáo (W. Harvey, 1628) pode-se admitir que a experimentaçāo se tornou a condição indispensável à investigação fisiológica.

Investigada e ensinada inicialmente com vistas à diagnose e à terapêutica, ou seja, conhecer o organismo para tentar descobrir os desvios de suas funçōes, a fisiologia passou crescentemente a ter também os objetivos acadêmicos de elucidaçăo de processos em termos estritamente biológicos. Sob esse aspecto, não se deve esquecer o lado biológico da obra de Aristóteles, cognominado o pai da história natural, que fez interessantes especulaçôes de cunho fisiológico, com intençōes fundamentalmente acadêmicas. Aliás, não seria despropositado recordar que, quando a filosofia e a ciência se confundiam, sempre tenha havido preocupação acadêmica da parte dos que, mesmo com intenções médicas, estudaram as funçóes. Em razão disso, a fisiologia, de longuíssima data, vem fazendo parte dos currículos das escolas de medicina, com o objetivo de dar aos estudantes embasamento biológico para as disciplinas clínicas e cirúrgicas. Assim, fica difícil, por sua condiçăo básica, que a 
fisiologia possa ceder completamente lugar nos currículos às disciplinas de cunho molecular em que se desdobrou. A passagem dos estudantes de medicina, ciências biomédicas ou biologia pela fisiologia tradicional continuará indispensável à formação do bom profissional ou pesquisador nessas áreas. Enfatize-se finalmente que a investigaçăo da fisiologia dos sistemas, de modo algum, acha-se esgotada e grande parte de seus experimentos clássicos ainda são importantes na pesquisa de ponta, tanto quanto didaticamente. Assim, respondendo a Frank, diria que a physiology does bave a future, ou, melhor, continuará sendo necessária sob as formas como é ensinada e pesquisada.

Mas não é somente a fisiologia como tradicionalmente é encarada que estaria em crise. Esta parece ter chegado também ao que se convencionou chamar fisiologia animal comparativa (FC), o estudo dos modos pelos quais mesmas funçóes são desempenhadas nos animais de diferentes filos, tendo em mira estruturas homólogas ou análogas, ou casos especiais (bioeletricidade, mudança de cor fisiológica, bioluminescência). A preocupação com essas questóes é bem antiga e, nos séculos $17 / 18$, famosos naturalistas deram à FC contribuiçôes importantes. Com o advento da doutrina da evoluçáo, sobretudo a partir de Darwin, deveria caber à FC subsidiar, em termos das funçóes, os achados morfológicos, embriológicos e paleontológicos relativos à filogenia animal. É o seu aparente fracasso nesse papel que está ressaltado num polêmico artigo em que Ross (1981) pretende desmistificar essa missão, afirmando que, afinal, a FC tem apenas contribuído para explicar como os animais lidam com situaçóes particulares, ou seja, é a fisiologia das adaptaçôes, na qual convergências antes que evolução das funçôes são detectadas. Essa crítica de Ross, a meu ver, é unilateral, não salientando a relevância de outros importantes objetivos da FC. Mas, sendo séria, merece ser comentada e, eventualmente, contestada.

Ross ressaltou inicialmente que a fisiologia comparativa tem sido um dos mais ativos setores da biologia na maior parte deste século, tendo aparecido como uma "nova zoologia", a emparelhar-se com velha zoologia estrutural, que levaria a descobertas relevantes, propondo questôes resolúveis pela experimentação. Com status comparável ao dos físicos (cujos métodos usavam), os fisiologistas comparativos, além de reformar a biologia, alargariam a base da fisiologia até então centrada experimentalmente no cão, rã e homem.

Ross é, para dizer o mínimo, cético em relação ao sucesso da FC, valendo-se de sua própria experiência, como se verá. A FC comparativa, admitiu, surgiu como a contrapartida da anatomia comparativa, no auge da época em que esta, juntamente com a paleontologia e a embriologia 


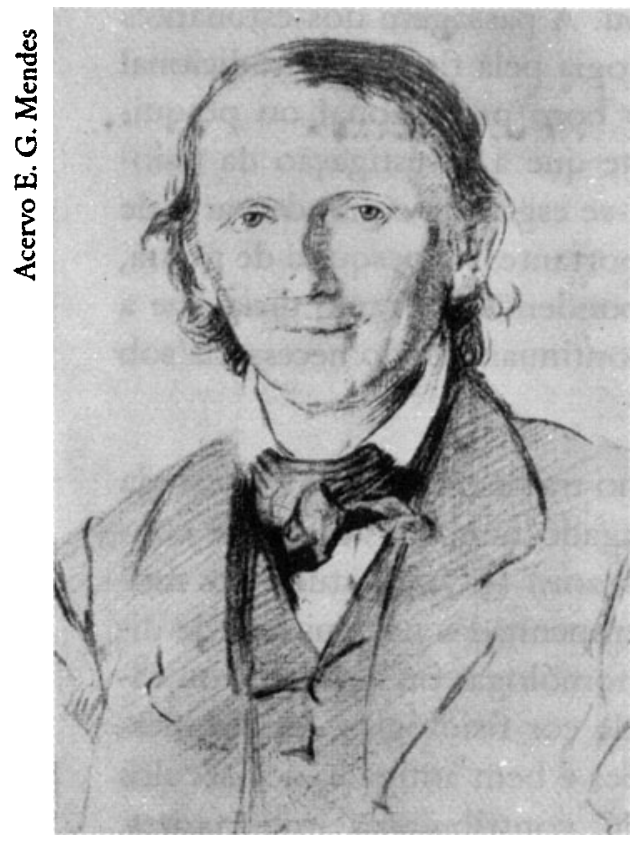

Carl Ludwig (1816-1895)

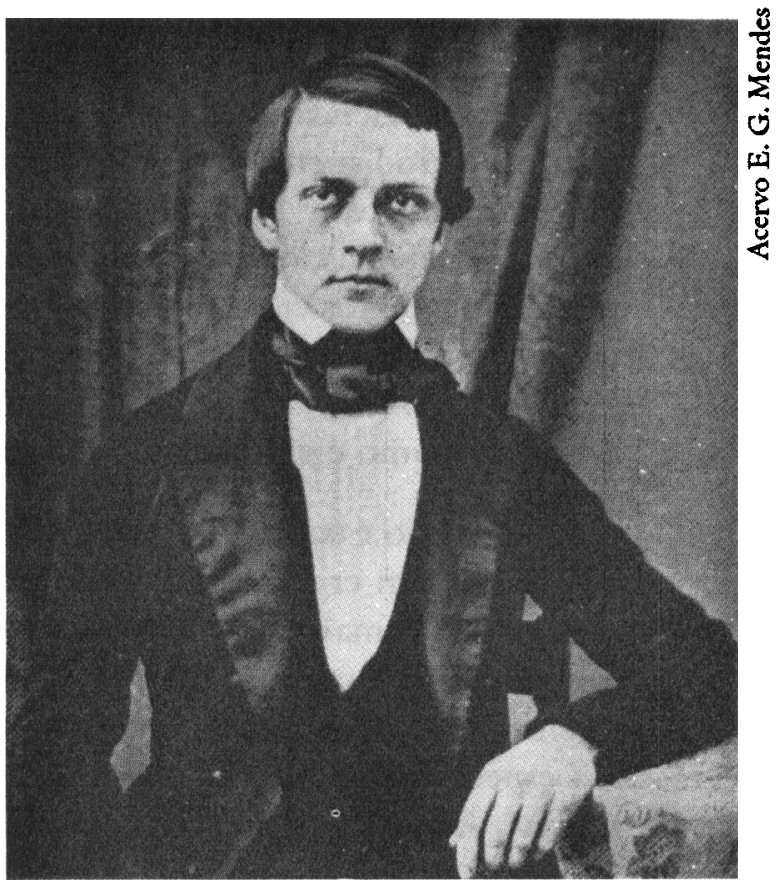

Hermann von Helmboltz (1821-1894)

contribuíam grandemente para a aceitaçáo da Evolução Orgânica como um fato. Nesse sentido, suas descobertas fundamentariam, em termos funcionais, os achados dessas ciências no campo da filogenia e esse, a seu ver, seria o propósito e a filosofia da FC, tal como originalmente teria sido concebida. E, aqui, começam as críticas de Ross.

Na realidade, segundo ele, em muitos casos o que resultou das pesquisas foi antes o estudo do modo como os animais lidam com circunstâncias peculiares, num tempo em que numerosos novos tipos de animais eram descobertos e muitos ambientes estudados pela primeira vez, sem significativas inferências sobre as origens e a filogenia das funçóes. Mesmo assim, a FC já se encontrava bem-estabelecida no início do século, especialmente na Alemanha, na Inglaterra e nos Estados Unidos, ocupando crescentes espaços nas revistas de zoologia e fisiologia, criando seus próprios periódicos e manuais, sinonimicamente rotulada de zoologia experimental ou zoologia fisiológica ou, ainda, zoofisiologia.

À vista desse sucesso, Ross julgou temerário criticar a FC, mas conta como lentamente foi se dando conta do que chamou as ilusóes e a realidade desse ramo da fisiologia. Canadense, recém-graduado no seu país, Ross procurou aprimorar seus conhecimentos, recorrendo a um dos mais renomados centros de zoologia experimental, sediado em 
Cambridge, aonde foi estudar com C.F.A. Pantin. Aí, além de Pantin, conviveu com J. Gray e um grupo de colegas entáo jovens, que o tempo iria notabilizar (J. Pringle, A. Ramsay, V. Rothshild, J. Harris, W.H. Thorpe, R.J. Pumphrey e H. Lissmann). Embora junto a tais sumidades tenha se sentido inferiorizado, já nessa época, começou a formular reservas quanto à $\mathrm{FC}$. Tendo adquirido a noção de que as grandes questóes em biologia são a origem da vida, a evolução, a hereditariedade, as adaptaçóes, a pendência vitalismo versus mecanicismo, não teria visto em Cambridge, preocupações com elas. No entanto, havia aportado entre os mais habilidosos e bem-informados pesquisadores, engajados em experimentos que requeriam engenho e fino tino de princípios científicos. Sobretudo, pareceu-lhe ambígua uma atitude do chefe do departamento, o grande J. Gray. Este trabalhava em estudo da função que implicava uma abordagem verdadeiramente comparativa, na qual princípios mecânicos envolvidos na locomoção de vários animais eram analisados com grande engenho e precisāo, levando a crer que ele admitia o mecanicismo como filosofia. Todavia, no discurso presidencial da BAAS (1933), The mechanical piem of life, Gray argüiu que a visão mecânica não explicava as propriedades especiais da matéria viva ou a origem da vida, uma opinião que, segundo Ross, náo era refletida nas suas pesquisas, de cunho mecanicista, como as da maioria de seus colegas de departamento, para os quais, no estudo de problemas, o que contava era não o que, mas como se fazia. Assim, pensando ter escolhido um campo florescente da zoofisiologia, Ross aí entrara só para se tornar unsettled face às atitude e circunstâncias encontradas.

Criticando a admissão tácita de que a FC tenha implicaçóes filogenéticas, Ross alinhou ilusões concernentes a essa admissão:

- a FC raramente teria confirmado significativamente as visóes hauridas da morfologia, paleontologia e embriologia de que as funções na escala animal poderiam ter evoluído segundo claros padróes filogenéticos e, sim, apenas teria demonstrado que o que ocorreu mais freqüentemente foram convergências;

- a FC não contribuiu para o esclarecimento de gaps na sucessão filogenética, nem corrigiu concepçóes errôneas, provendo alternativas.

Mais freqüentemente, comparaçóes funcionais converteram-se em paradoxos e não paralelos filogenéticos (caso, por exemplo, dos pigmentos respiratórios, neurotransmissores, mecanismos de contração muscular). Por outro lado, mecanismos fisiológicos servindo a um mesmo propósito mostram grande diversidade (visão, mudança de cor, bioluminescência) e, menos freqüentemente, evoluíram segundo uma linha filogenética discernível (excreção, sistema nervoso). Assim, a impressão que fica é que os animais, de todos os níveis, possuem o equipamento 
requerido para seus particulares modos de vida, sem muita referência à história filogenética.

Entre as realidades, Ross destacou que a já vastíssima literatura em FC consiste (ainda que não declaradamente) mais comumente de descriçōes de adaptaçōes, sendo apropriado dizer que os fisiologistas comparativos se ocupam de como os animais funcionam. Há dificuldades em se conceituar a FC: "náo tanto uma disciplina definida quanto um ponto de vista, uma filosofia, (...) aquele método que usa o tipo de animal como uma variável experimental" (C.L. Prosser); "definível como o estudo de similaridades e diferenças entre entidades biológicas" (T.H. Waterman); "a análise da adaptação que adequa o sistema à demanda ambiental" (D. Kennedy). Neste último sentido, os organismos evoluíram, dentro de planos estruturais definidos, para sobreviverem em todas as condiçóes possíveis. Todavia, segundo Ross, descrever e interpretar adaptaçóes não conduziria à descoberta de novos princípios gerais biológicos. Ainda assim, a FC valeria como disciplina acadêmica e, pela sua contribuição à medicina humana e veterinária, teria servido para esclarecer fenômenos fisiológicos fundamentais (ver, por exemplo, os casos dos neurônios identificáveis de certos moluscos e insetos no entendimento de padróes comportamentais). Em que pese o fato de que a FC possa ser criticada por vir sendo antes seletiva que comparativa, fundando suas inferências ainda em estudos em umas poucas preparaçōes, Ross reconhece-lhe esse valor de continuar a fornecer à fisiologia geral tais preparaçóes para a investigaçáo de cunho básico (o primeiro trabalho que estabeleceu a acetilcolina como neurotransmissor dependeu da sensibilidade à mesma do músculo da sanguessuga).

A meu ver, essa crítica de Ross é, como disse, unilateral e, em muitos aspectos, em desacordo com a história da FC. Não procederia que ela teria surgido apenas da necessidade de se criar uma contrapartida fisiológica de estudos morfológicos comparativos e palentológicos que levaram a especulaçóes sobre a filogenia animal. Esta pode ter sido uma das suas motivaçóes, ainda que tardia. Tendo freqüientado no país e no exterior cursos de FC, apenas incidentalmente ouvi referências acerca de tal propósito da FC. Na verdade, como acenado anteriormente e o próprio nome indica, a FC é fundamentalmente o ramo da fisiologia que se ocupa de investigar como mesmas funçóes são desempenhadas em estruturas homólogas e análogas nos animais de vários filos, comparando esses modos e relacionando-os no que têm em comum e no que respeita a adaptaçóes a diferentes ambientes. Essa atividade pressupóe evidentemente conhecimentos de zöologia básica e morfologia comparativa. Se, ao tempo em que a doutrina da evoluçáo se firmava, houve a intenção de comparar as funçóes nos vários filos visando-se a subsidiar 
achados morfológicos e paleontológicos, esse não foi o móvel primordial da FC e, sim, uma atitude natural em uma época na qual essa evolução, com Darwin e seus fiéis seguidores Huxley e Haeckel, configurava uma revoluçăo científica a que cumpria de alguma forma aderir. Cabia pois tentar demonstrar que as funçóes também tinham evoluído em paralelo com as formas e até se explicariam recorrendo-se a estágios anteriores. Nesse sentido até que a FC năo se deu inteiramente mal, sendo numerosas as instâncias nas quais sua contribuiçáo foi relevante.

Entre os casos mais citados, cumpriria ressaltar:

- o aparente contra-senso de, no rim do vertebrado superior, haver antes uma grande filtraçáo do conteúdo aquoso do sangue, que, depois, é quase todo reabsorvido - o que se explicaria na base da evoluçáo a partir de peixes d'água doce, onde essa grande filtraçáo evita hidratação, mas, no caso dos vertebrados terrestres, poria em perigo a economia de água;

- a evoluçáo do próprio sistema excretor na série animal, com base num plano anátomo-funcional (aparelho terminal + sistema de canais), do protonefrídio de invertebrados ao metanefros dos vertebrados;

- a evolução do sistema nervoso da rede nervosa dos celenterados ao tipo centralizado, condizente com a passagem da simetria radial à bilateral e o surgimento da cefalizaçáo.

Outros exemplos poderiam ser dados e, se se considerar, com Ruffini (1925), que "a forma é a imagem plástica da funçáo", poder-se-ia aceitar, admitida a evoluçáo da forma, ficar implícita a da função, o que, todavia, nem sempre é fácil demonstrar, ensejando a crítica de Ross.

A FC, assim, não seria invalidada pelos casos em que não teria demonstrado a evoluçăo das funçóes em paralelo com a das formas. Os seus objetivos, na verdade, remontam a bem antes do advento da moderna doutrina da evoluçáo, sendo antiga a tendência dos homens da ciência, com fins comparativos ou não, de saber como os animais comem, digerem, respiram, excretam, sentem e exibem comportamentos, sem preocupaçôes de ordem filogenética. Tratou-se de uma curiosidade natural desses cientistas, aliada muitas vezes à preocupaçáo de estudar forma \& função com objetivos inclusive de proteçáo de espécies úteis e debelaçáo das nocivas. Neste último sentido, vale o registro de Wigglesworth (1939) de que a FC serve para o esforço de "quebrar a armadura ecológica" dessas espécies daninhas. No passado, sobretudo nos séculos 17/18, salientaram-se os italianos F. Redi (1626-1697), ocupando-se da sede de produçáo, natureza e modo de inoculaçáo do ve- 
neno da víbora e pesquisou a digestão e circulaçáo nos insetos; $M$. Malpighi (1628-94), descrevendo a forma e a funçáo de inúmeras estruturas animais que levam o seu nome e, por ter descoberto os capilares, dele se disse "Harvey fez dos capilares uma necessidade lógica, Malpighi uma certeza histológica" (a descoberta foi feita no pulmão e no mesentério da rã); esse admirável e multiforme L. Spallanzani (1729-99), estudando a fisiologia da respiração, circulação e digestão em vários animais, o órgão elétrico dos peixes e suspeitou de um sexto sentido nos morcegos.

Os poucos casos citados em que fica cientificamente aceitável a contribuição da FC à história filogenética, acrescidos dos desses prodigiosos italianos já configuram parcialmente objetivos desse ramo da fisiologia que Prosser, na primeira ediçáo de seu Comparative Animal Physiology, incorporou no elenco de finalidades da mesma, a saber:

- descrever os modos diversos pelos quais diferentes tipos de animais enfrentam suas necessidades funcionais;

- elucidar as relaçóes evolucionárias dos animais pela comparação de características fisiológicas e bioquímicas;

- prover base fisiológica à ecologia, descrevendo os mecanismos de tolerância aos estresses em habitats particulares e as adaptaçóes funcionais que subjazem à extensa gama de uma população;

- chamar a atençáo para preparaçóes animais particularmente adequadas à demonstraçáo de funçóes específicas; $\mathrm{e}$

- conduzir às amplas generalizações biológicas que surgem do tipo do animal como uma variável experimental.

Desse elenco, depreende-se que a FC trata da função animal em nível de órgão e animal inteiro, integra e coordena relaçóes funcionais que transcendem de grupos especiais, diz respeito aos modos pelos quais organismos diversos têm funçőes semelhantes, porque animais geneticamente diferentes mostram similaridades em características ou resposta a mesmo estímulo ambiental e, de maneira recíproca, animais intimamente aparentados freqüentemente reagem de forma muito diversa a uma mesma circunstância.

Quanto a prover base fisiológica à ecologia, bastaria recordar que o ecólogo Margalef (1974) considera a sinecologia (e muito mais seria a autoecologia) uma fisiologia praticada ao ar livre. Cadeias alimentares, interdependências, predaçóes, autodefesas e atraçōes por meio de agentes químicos, tudo isso requer abordagem de cunho fisiológico comparativo.

Chamar a atenção para preparaçôes animais particularmente adequadas à resoluçáo de questōes básicas da fisiologia tem sido ultima- 
mente a faceta mais destacada da FC. Por ocasião da aposentadoria de C.L. Prosser vários cientistas contribuíram com artigos em sua homenagem, aparecidos no volume 194 (1975) do Journal of Experimental Zoology. Hans Krebs (1975), nobelista e conhecido pelo ciclo bioquímico que the leva o nome, escolheu escrever sobre o chamado Principio de Krogh. August Krogh, outro nobelista por seus trabalhos sobre capilares e provavelmente o maior dos fisiologistas comparativos, contou, numa lecture durante o XIII Congresso Internacional de Fisiologia (1929), que, certa vez, no laboratório de Christian Bohr em

\section{Marcello Malpighi \\ (1628-1694)}

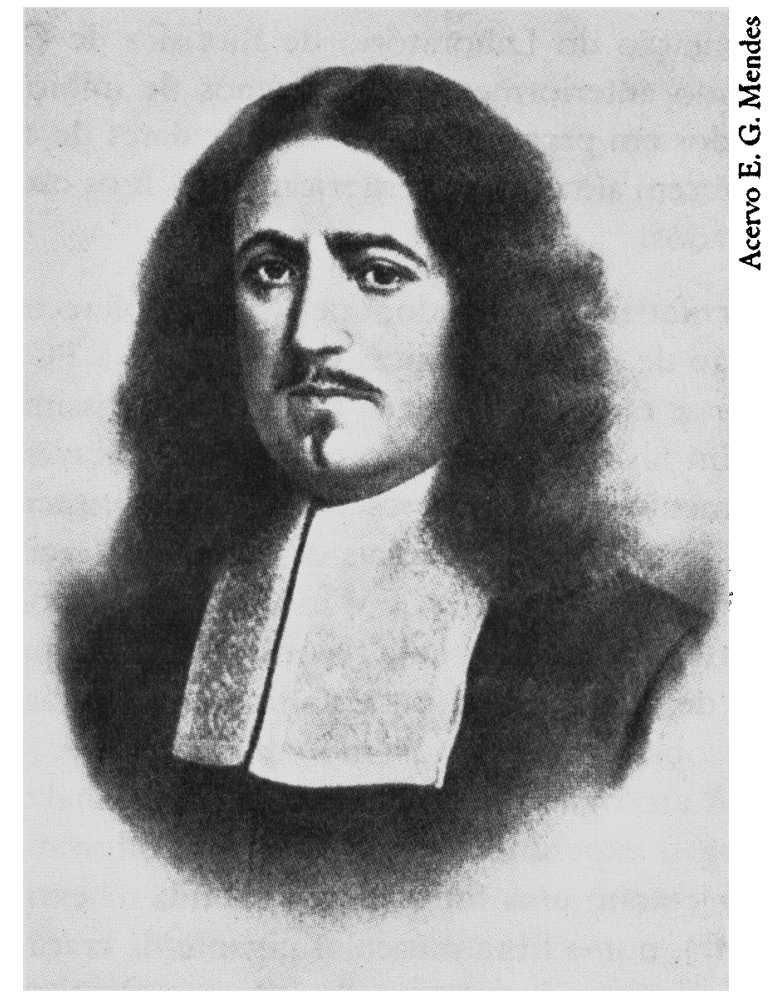

Copenhague, trouxeram uma tartaruga que tinha uma curta traquéia e dois longos brônquios principais e, assim, se adequava ao estudo de cada pulmáo isoladamente. E, adiantou, deveria haver inúmeros outros animais igualmente adequados à experimentação, que caberia aos zoólogos apontar. Tal adequação passou a configurar o princípio que tem o seu nome: "Para muitos problemas há um animal no qual podem ser mais convenientemente estudados".

A lista de tais animais já é grande; bastaria recordar que a Genética 
se beneficiou enormemente da existência da mosca Drosophila (Morgan, Sturtvant) e que várias questóes básicas da fisiologia foram resolvidas usando-se não somente vertebrados inferiores, mas também invertebrados. Houve até casos curiosos como o da descoberta do evento inicial da visão, feita nos anos 20 por S. Hecht, ao estudar a cinética da resposta do sifăo fotossensível de um mexilhão ( $M y a$ ). Muitas das dificuldades do entendimento biofísico da gênese e da propagaçáo do impulso nervoso foram resolvidas com o emprego do axônio gigante da lula, que o zoofisiologista J.Z. Young indicou a K.S. Cole, recomendado por este a Hodgkin e seus colegas de Cambridge. O órgáo elétrico do nosso poraquê, animal de escolha para o estudo da transmissão neuromuscular, fez a reputação do Laboratório de Biofísica de Carlos Chagas Filho, mencionado anteriormente. Fenômenos de inibição nervosa săo bem investigados em preparaçóes neuromusculares de crustáceos superiores por ocorrerem aí também perifericamente. $\mathrm{E}$ os exemplos poderiam ser multiplicados.

Reenfatize-se, contudo, que além de oferecer o animal adequado à resolução de questóes básicas da fisiologia, a FC se impóe como disciplina desse ramo da biologia. Os interessantíssimos episódios da vida animal têm histórias fisiológicas atraentes a desvendar e contar, dando não raramente azo a bizarros tipos de experimentaçáo, em que, por exemplo, misturam-se materiais de animais diferentes para a investigação de função de um deles. É o caso abordado por Greenberg (1985), em um artigo no qual começa recordando a cena primeira do IV ato do Macbeth de Shakespeare, onde as bruxas misturam num caldeirão pedaços de cobras, lagartos, rãs, morcegos e corujas for a charm of powperful trouble. A analogia moderna dessa metáfora shakespeareana seria para Greenberg o experimento de Ashley \& Ridgway (1968), em que os autores injetaram uma fotoproteína, obtida de extratos de uma medusa (Aequorea), numa fibra muscular gigante da craca (Balanus ) e, como ela bioluminesce em presença de íons de cálcio, puderam seguir o caminho intracelular do íon durante a estimulação nervosa do músculo. $O$ extravagante título dado ao artigo por Greenberg (Ex-bouillabaise: lux...) é sugestivo, pois, no caso do experimento, houve conceitualmente tanto quanto literalmente produção de luz. É o experimento favorito de Greenberg, pois captaria a essência da fisiologia e bioquímica comparativas, em particular seu potencial para trazer luz proveniente de sopa.

Bouillabaises, de fato, são freqüentemente preparadas por fisiologistas comparativos. Eu mesmo já preparei tais sopas, como no caso em que, impossibilitado circunstancialmente de identificar quimicamente um princípio ativo extraído de um caracol, vali-me de bioensaios nos quais usei várias preparaçóes de músculos de invertebrados para, 
conhecendo suas exclusividades no tocante aos receptores de membrana, excluir ou demonstrar a possibilidade desse princípio ser um determinado neurotransmissor.

Kuhn (1970) descreveu os três estágios em que a ciência se desenvolve. No primeiro (pré-paradigmático ou imaturo) não há consenso governante sobre as hipóteses condutoras. No segundo (maduro), a ciência é unificada e dirigida por um consenso sobre as hipóteses estruturadoras, cujo conjunto forma o paradigma do campo investigado. Enquanto houver consenso sobre esse paradigma, tem-se a ciencia normal. O terceiro estágio sobrevem quando esse consenso se rompe, um evento chamado por Kuhn de crise e a ciência passa por um período de debates sobre as hipóteses vigentes, a ser resolvido pela formação de um novo consenso referente a novo conjunto de hipóteses condutoras, que configura uma repoluģão cientifica.

A vista do exposto e comentado sobre as supostas crises na fisiologia tradicional e na FC, dificilmente poder-se-ia admitir estar havendo ou se delineando nesses campos de investigação uma revolução nos moldes kuhneanos, implicando um novo paradigma. Se crises houve na fisiologia, elas remontariam, por exemplo, ao tempo em que explicaçóes para os fenômenos fisiológicos faziam apelo a esdrúxulos flogístico e espiritos (Galeno) e ao recurso à vis vitalis, quando se tornou imperioso que as explicações passassem a ter cunho experimental, com frequiente uso de procedimentos físicos e químicos e o apelo à força vital tornou-se inaceitável como via de investigação.

O valor dado à experimentaçáo como o meio de elucidar fenômenos fisiológicos se coaduna com o principal dogma do positivismo, como formulado por David Hume e os enciclopedistas franceses no século XVIII, segundo os quais a experiência é a única fonte do conhecimento e os métodos da ciência empírica são os únicos meios pelos quais o mundo pode ser entendido. Mesmo em face de um neovitalismo corrente, essa atitude positivista na fisiologia, pelo menos no que respeita às funçóes ditas vegetativas, não sofreria a crítica que modernamente se faz à doutrina de Hume, sendo certo que fenômenos tais como, por exemplo, a digestão, se elucidam maiormente pela experimentação, usando-se procedimentos físicos e químicos e o conhecimento anatômico. As dificuldades surgem quando se trata de funçóes neurossensoriais nas quais ficaria menos aceitável a visão positivista de ser a mente um papel em branco, em que gradualmente se escreve uma representação da realidade constituída com a experiência cumulativa. Modernamente, essa visão vem sendo posta $\mathrm{em}$ cheque e ganha terreno a admissáo de que a mente, como queria Kant com seus conceitos trans- 
torna-se-ia não apenas plausível, mas inteiramente de acordo com a corrente principal do pensamento evolucionista. Conceitos a priori de tempo, espaço e causalidade são intuitivamente óbvios e compreendidos por cada criança no curso de seu desenvolvimento intelectual normal, sem necessidade de aulas de física, porque determinantes hereditários de nossas funçóes mentais superiores foram selecionados por seu ajuste evolucionário, tal como genes que dão origem a atos comportamentais inatos, como o sugar do seio materno, que náo requerem apendizagem por experiência. A importância dessas consideraçóes darwinianas transcendem uma mera invocaçăo da epistemologia kantiana, pois a origem evolucionária do cérebro explicaria não apenas porque nossos conceitos inatos se adequam ao entendimento do mundo, mas também porque esses conceitos não são tão válidos quando se tenta sondar esse mundo nos seus aspectos científicos mais profundos.

Além de explicar em termos evolucionários como o cérebro humano e seu epifenômeno, a mente, adquirem conceitos a priori, a biologia moderna também indicaria que o cérebro opera segundo os princípios do estruturalismo, no sentido de os estudos neurológicos mostrarem que, de acordo com esses princípios, a informaçáo sobre o mundo alcança as profundezas da mente, não como um dado cru, mas como estruturas altamente processadas, geradas por um conjunto de transformações informacionais graduais e pré-conscientes do input sensorial. Essas transformaçóes neurológicas processam-se de acordo com programa que pré-existe no cérebro. Assim, achados neurológicos dariam cendentais ou a priori, constrói a realidade a partir da experiência à custa do conhecimento inato.

Esse modo de ver estaria em consonância com a doutrina da evolução. K. Lorenz (1939) lembrou que, embora poucos cientistas tivessem se dado conta do fato, o dilema proposto pelo a priori kantiano reabriu-se quando Darwin formulou a teoria da evoluçáo na segunda metade do século XIX. Segundo Lorenz salientou, o argumento de que o conhecimento sobre o mundo entra na mente apenas pela experiência pode ser válido se for considerado tão somente o desenvolvimento ontogenético do homem. Mas, quando se tem em conta o desenvolvimento filogenético do cérebro através da história evolucionária, tornar-se-ia claro que os indivíduos podem saber alguma coisa do mundo também inatamente, antes $e$ independentemente de suas próprias experiências. Afinal, não haveria razão biológica pela qual tal conhecimento inato não pudesse ser transmitido de geração a geração pelo conjunto de genes que determina a estrutura de nosso sistema nervoso. Pois esse conjunto de genes tornou-se realidade através da seleção natural operando em nossos remotos ancestrais. Assim, a noçáo kantiana do conhecimento a priori 


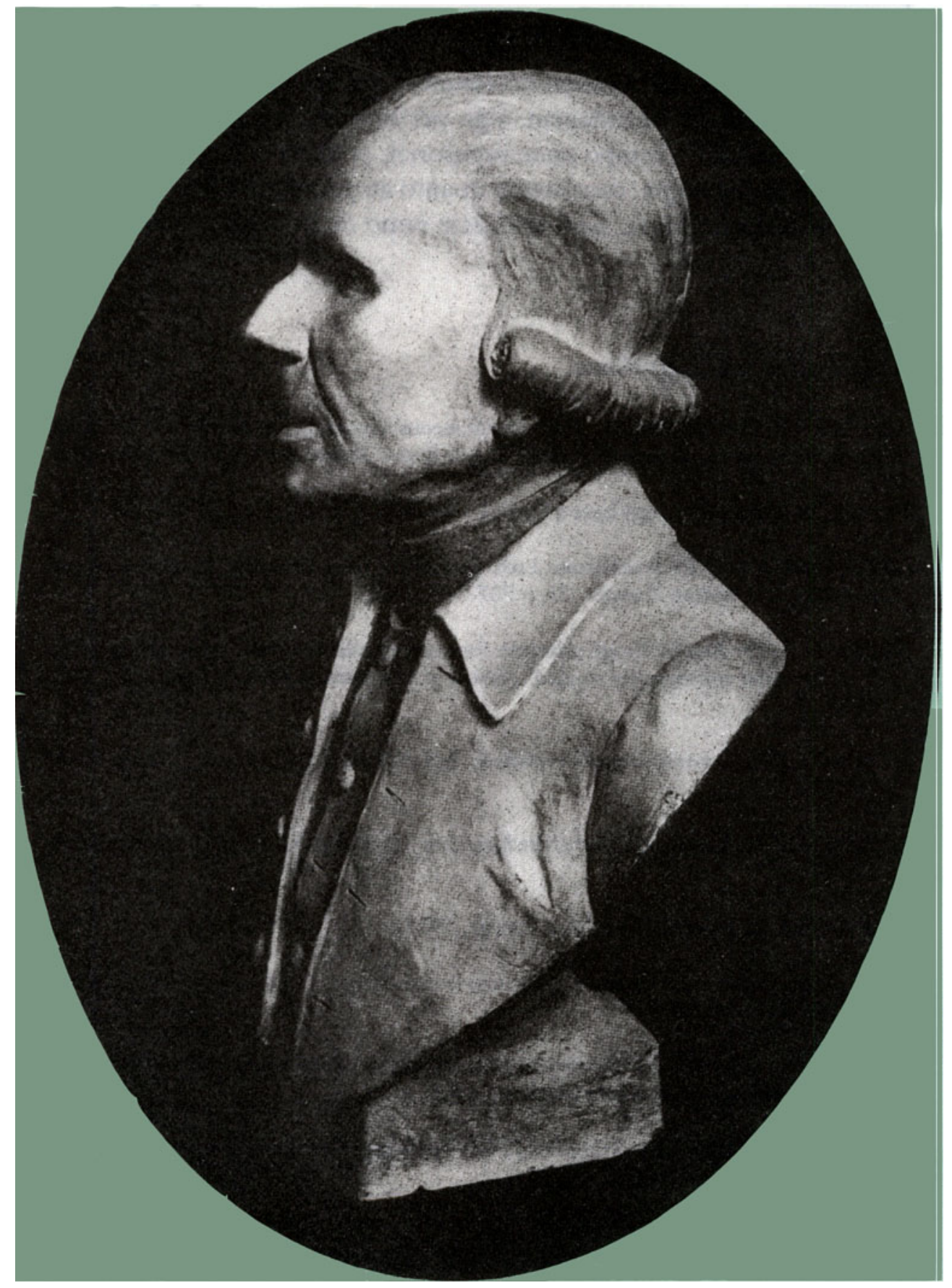


apoio biológico ao dogma estruturalista de que as explicações do comportamento deveriam ser formuladas em termos de tais programas e revelariam o erro da abordagem positivista.

A discussão mais extensa do assunto foge ao escopo principal deste artigo, mas a sua abordagem, algo perfunctória aqui, deixa entrever que, pelo menos no campo neurossensorial, poderia estar se esboçando uma crise na fisiologia, consistente quanto ao paradigma positivista poder estar cedendo lugar, também nesse ramo da biologia, ao estruturalista.

\section{Referências Bibliográficas}

ASHLEY, C.C. \& RIDGWAY, E.B. Simultaneous recording of membrane potential, calcium transport and tension in single muscle fibres. Nature, 219, p.1168-1169, 1968.

FRANK, M. Does physiology have a future? The Plyysiologist, 29, p.1-2, 1986.

GREENBERG, M.J. Ex Bouillabaise Lux: The charm of comparative biochemistry and physiology. American Zoologist, 25, p.737-749, 1985.

KREBS, H.A. The August Krogh principle: for many problems there is an animal on which it can be most conveniently studied. Joumal of Experimental Zoology, 194, p.221-226, 1975.

KUHN, T. The stmucture of scientific revolutions, 2nd ed. Chicago, University Chicago Press, 1970.

LORENZ, K. Vergleichende Verhaltensforschung. Zoologischer Anzeiger, 12, p.69-102, 1939.

MARGALEF, R. Ecologin. Barcelona, Omega, 1974.

ROSS, D.M. Illusion and reality in comparative physiology. Canadian Journal of Zoology, 29, p.2151-2158, 1981.

RUFFINI, A. Fisiogenia. La biodinamica dello swiluppo e i fondamentali problemi morfologici dell 'mbriologia generali. Milano, Vallardi, 1925.

WIGGLESWORTH, V. The Principles of Insect Physiology. New York, Dutton, 1939.

\section{Resumo}

O autor se reporta a apregoadas crises tanto na fisiologia, como é classicamente entendida, como na que se convencionou chamar fisiologia animal comparativa. $\mathrm{Na}$ primeira, a crise residiria em estar cedendo lugar às disciplinas em que se desmembrou (biofísica, bioquímica, farmacologia e, mesmo, imunologia) c cada vez menos tendo a possibilidade de fazer pesquisa de ponta. $\mathrm{Na}$ segunda, o 
sentido da pesquisa teria divergido do concebido pelos seus instituidores, que deveria ser o de subsidiar as análises filogenéticas hauridas da anatomia, embriologia e paleontologia. Enfatiza que as referidas disciplinas continuam fisiologicas, a visão holística propiciada pela fisiologia clássica persiste importante e seus problemas de natureza sistêmica estão longe da elucidação satisfatória. Também năo procederia a crítica feita à fisiologia comparativa de fracasso nas tentativas de compatibilizar as funçōes com a filogenia, pois, em casos significativos houve sucesso. Ademais, a fisiologia comparativa, na evoluçăo de seus objetivos, ganhou novas conotaçöes, mormente a ecológica, em que convergências antes que alinhamentos filogenéticos são buscados. Além disso, essa fisiologia tem oferecido à pesquisa básica animais, modelos experimentais mais simples, extremamente adequados ao estudo de funçōes complexas. Assim, nāo haveria crises num sentido de perda de objetivos ou mudança de paradigma nos dois casos. Novos rumos? $O$ autor admite novos delineamentos nos estudos de problemas que continuam fundamentalmente os mesmos. Um breve aceno ao caráter prevalentemente positivista da fisiologia é também feito.

\begin{abstract}
The author reports on proclaimed crises in classical physiology as well as in the so-called comparative animal physiology. In the former, the crisis would derive from loosing grond to biophysics, biochemistry, pharmacology and, even, immunology in a manner detrimental to holistic and systemic views; lack of opportunity to do cutting edge research is also pointed. In the latter, the trends followed in the researches would be far from the purpose originally conceived of subsidizing the phylogenetic analyses based on comparative anatomy, embryology and paleontology. The author emphasizes the undiminished importance of classic physiology, of which biophysics and biochemistry are but specialized branches and recalls that the holistic view and the systemic approach remain as the ultimate goal of physiology. As to comparative physiology, claims of failure to accomplish the alleged original purpose are to be rejected, in view of sucesses reported in tracing the evolution of functions and the fact that, with time, comparative physiology gained new connotations, mostly ecological, dealing with convergences rather than phylogenetic alignnients. Besides, this branch of physiology has continuously furnished animal models for basic research. Thus, there would be no crises in a philosophical sense of loss of objectives or paradigm change, but rather a growth crisis towards molecular approaches. Essentially, not new trends, but new experimental designs. A brief reference to the prevalent positivist character of physiology is also made.
\end{abstract}

Erasmo Garcia Mendes é Professor Emérito do Instituto de Biociências da Universidade de São Paulo, titular aposentado da disciplina de Fisiologia Animal II e integra a Mesa Editorial da revista Estudos Avançados.

Este trabalho foi desenvolvido a partir de uma palestra feita pelo autor no seminário "Novos rumos em Fisiologia Animal Comparativa", realizado de 15 a 19 de fevereiro de 1989, no Centro de Biologia Marinha da Universidade de São Paulo, Săo Sebastiāo, Litoral Norte. 